\title{
Black self-hatred: Regaining self-worth - From decolonisation towards reconciliation in South Africa - A practical theological appraisal
}

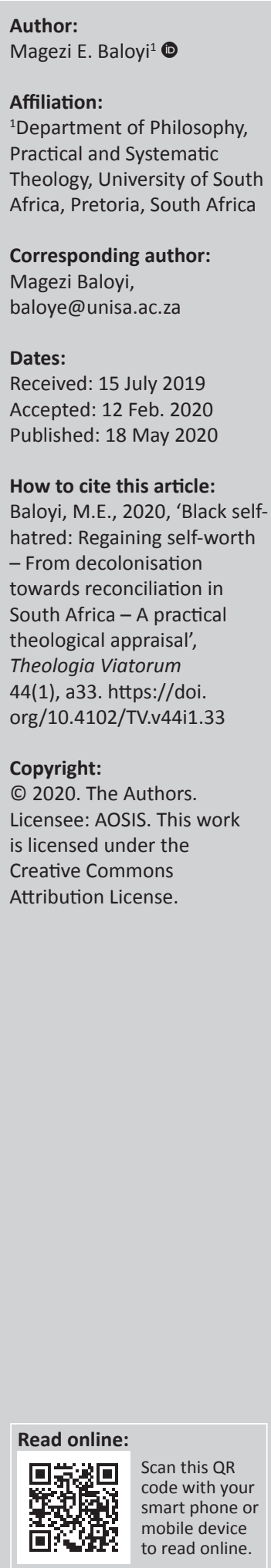

The black-on-black violence that typifies the present-day South Africa, amongst other things, manifests itself in different forms, for instance, mob justice, xenophobia, black undermining and even harassing another black person in the workplace, along with other signs of an inferiority complex. The affirmation of 'Black is Beautiful', which was a popular slogan used by the slain Black Consciousness leader, Steve Biko, finds slippery ground to resonate amongst the black masses today; hence, the manifestation of self-hatred still has a space within black communities. It is the continuity of this pathology, from an outward look to inward thinking, decisions and actions that deprives African people of a chance to make an impact in respect of self-worth, decolonisation and reconciliation. As much as people can blame the slow pace of the transformation agenda in South Africa, it is equally important to determine the role of inflicted self-hatred as a factor in the process. It is a bone of contention that being truthful to self-worth and self-esteem takes courage to make us active participants in our decolonisation, which will ultimately play a role in the reconciliation of the previously (and presently) divided South Africa.

Keywords: black-on-black violence; practical theology; Steve Biko; self-worth; decolonisation.

\section{Introduction}

In his Senate opening of a meeting on 24 October 2018, Prof. Mandla Makhanya indicated that colonisation had succeeded in putting native people in a space where they are not who they want to be. Black people have simply become shadows of themselves, have no longer been able to define or even identify with their real selves and have been living to please their colonisers. It is from this opinion, amongst others, that I see the problem of black self-hatred as a serious issue that needs to be addressed. I am convinced that decolonisation is one of the slowest of all the projects involved in transformation, but for me one of the causes is the black self-hatred that manifests itself in many forms in our daily lives. In his book entitled Black Christians, the Bible and Liberation, Prof. Takatso Mofokeng (1988:35) emphasises the point of self-hatred thus: 'In order to do black theology one needs to first love blacks, but blacks are not lovable (even to themselves)'. It is this kind of understanding which I take a very serious look at, in this article. Although Baldwin's (1979:58) notion of black self-hatred is perceived from an African-American context, it does play a role in assisting us to see how deeply entrenched self-hatred has become in the lives of black people in Africa. It is from within black hatred that people start despising their own culture and traditions, as exemplified in the statement: 'Only fools pay lobolo' (Writer 2012).

It is the author's conviction that, finding ourselves after colonialism and racism, it is important to also deal with the issue of self-hatred, which demands that we realise what Steve Biko (1978) indicated when saying:

No wonder the African child learns to hate his heritage in his days at school. So negative is the image presented to him, that he tends to find solace only in close identification with the white society. (p. 32)

Black heritage is at the top of the agenda on issues of transformation, because as black people, we have despised our heritage for many decades. The issue of self-hatred is not unfamiliar to many Africans, be they Christians or non-Christians. One of the central postcolonial challenges is the self-hatred which the author perceives to have been entrenched by the racial inequalities of the past. The justified hegemonies of the oppressed, as participants in their own oppression, receive support from Tshaka (2013:186), and Tsitsi Dangarembga (Quoted in Tshaka) who witnesses that the internalisation of self-hatred goes even deeper than can be imagined. 
In his blog entitled 'The South Africa we do not want to know', Vusi Gumede (2016) is correct in saying:

Because the government is increasingly losing credibility, white people have acquired another ticket to disrespect the majority with impunity. And indeed the majority allows this, because whiteness is viewed as sacrosanct. The system was configured in such a way that even today the majority spends more time worrying about white people, and their white justice/law against their white crimes. Many Africans have been so preoccupied with the Oscar Pistorius case, as an example. When Sindisiwe Manqele was incarcerated for 12 years, possibly for defending herself, the silence among Africans was deafening for instance: most Africans find themselves in a helpless psychosocial 'space' which clouds them and pays undue attention to wrong things instead of self-advancement and playing part in taking South Africa forward, among other important things. Most Africans go to white churches where white priests tell them that Africans are subhuman. Most Africans adore whiteness, as Caribbean scholar and intellectual activist Ama Mazama says, and to the extent that we dream of a white Jesus Christ (Mazama 2015).

Evidence of black-on-black violence, crime, xenophobia, Afrophobia and dishonesty as direct opposites of how black people behave towards their white colonial masters is enshrined amongst African people (Ashimolowo 2007:176). It is therefore the gist of this article to research, by way of reading, listening to news on television and radio, as well as following other media statements, to theologically argue that the attitude of black self-hatred is impeding our own decolonisation. The aim of this article is to investigate not only how this self-hatred was planted in black people's minds but also how practically this very old-fashioned trend continues to manifest itself within black South Africans. It is also imperative to make theological and practical suggestions as to how to directly (or indirectly) stop this pathology from continuing to subject the black masses. The author supports Julius Malema's statement that if Africans unite, colonialism will never succeed (Mathope 2017).

\section{Problem statement and importance of the study}

According to Charles (in Senokoane 2019:2), in his article 'Escape of the black self', there is evidence in many parts of the world, including Jamaica, that black people have tried to 'become white'. An example from South Africa is that of Mshoza, a black musician who tried to bleach her skin to become what is popularly known as 'a yellow bone'. The problem is, firstly, that white people are not attempting to become black. Secondly, this only helps to destroy black culture, and our identity as black Africans. Masenya (2018:145) brings in a crucial discussion when she questions whether black-on-black violence is not a manifestation of self-hate and self-negation, which are the embodiment of an inferiority complex. It is my contestation that some of these violent acts will not easily be done away with, if we do not make time to research self-hatred that comes as a package with colonialism. The challenge to decolonise our higher education system, as demanded by the \#FeesMustFall campaign in 2015, is a hurdle that still needs to be overcome.
Before we can even ask who is qualified to decolonise our education, it is imperative to address self-hatred, which is accompanied by self-neglect, as well as a tendency to look at ourselves as perennial shadows of our former colonialists. It is the cause for concern that black Christians are often perceived as African Christians who fail to live up to their Christian profession in times of crisis and are thought to resort to a struggle with the spirit world to solve their daily life struggles (Kunhiyop 2009). This notion, for me, stems from the fact that, from the onset, theology came from the West and did not commit to being relevant in the lives and challenges black people are facing; hence, the use of such a theology for survival is often a tough nut to crack. It is for that reason that some black people who want to please their colonial masters pretend to agree with everything theologically, until a crisis sends them back to their origins. It is for that reason that I am in full agreement with Martey (2013:226), in arguing that African theologians need to provide an analytical critique that will be able to inform, educate and transform African religio-cultural action in a positive way, to effect healing to human brokenness and bring about authentic liberation. Mkhize et al. (2010), in their book The Country We Want to Live In, expose how self-hatred manifests itself through black people becoming the enemies of their black lesbian brothers and sisters. For me, authentic liberation implies doing away with the hypocrisy that promotes self-hatred towards the black masses.

\section{Reasons why the discussion on black self-hatred is relevant today}

Highlighted in Tapper's (2009:1) article entitled 'Self-hatred leads to skin-bleaching' is a discussion with a woman from Ghana who states: 'When you are lighter, people pay more attention to you. It makes you more important and the rich men find you attractive'. This is one way of portraying the self-hatred that many black people experience. There is enough evidence to show that the current South African situation is typified by the fissures of the past, which still hurt the country in many forms, including tribalism. The workplace and other spheres bear evidence that black leadership is often despised, undermined and misjudged by the black masses, while white leadership still enjoys support and preference. Reconciliation becomes more difficult when such discrepancies are still at work to promote black selfhatred, which shows itself in the form of xenophobia and Afrophobia. Black-on-black violence has become the order of the day, for instance, in townships where mob justice and suspicions of witchcraft are prevalent. Readings such as Black Skin, White Masks, by Franz Fanon (1952) help to explain clearly that self-hatred can also be used to slow down the reconciliation processes.

In a report by Shange (2018), entitled 'Six hate crimes that shocked South Africa', a few incidents are mentioned in which black people killed their fellow blacks, and such incidents continue to instil fear of a fellow brother or sister. Such incidents include the killing of the Mozambican-born Emmanuel Sithole who was stabbed to death in Alexandra 
township during the xenophobic attacks of the year 2015. It includes the case of Lerato Moloi, a lesbian from Naledi, who was found raped, beaten and stoned to death in May 2017.

\section{Bell Hooks (1992) is correct when saying:}

I was painfully reminded of this fact recently when visiting friends on a once colonised black island. Their little girl is just reaching that stage of preadolescent life where we become obsessed with our image, with how we look and how others see us. Her skin is dark. Her hair chemically straightened. Not only is she fundamentally convinced that straightened hair is more beautiful than curly, kinky, natural hair, she believes that lighter skin makes one more worthy, more valuable in the eyes of others. Despite her parents' effort to raise their children in an affirming black context, she has internalised white supremacist values and aesthetics, a way of looking and seeing the world that negates her value. (p. 3)

This quotation may sound as if nothing serious is wrong, but the self-rejection that is depicted by the view of the little girl about herself as a person is very concerning. This resonates with Chanel Donaldson's (2018:1) views on of what she calls 'slavery and the internalisation of white standards of beauty'. Dismissing all hair-straightening practices as a form of hatred is, for her, an over-simplification that fails to take the historical context and culturally embedded motivations into consideration.

In essence, colonialism that aimed to make the white man 'the predestined master of this world' influenced the colonial masters to ensure that everything about black people- their culture and traditions - was relegated and labelled as bad or pagan. That is why wherever colonialists came to invade any African country, shifts in language and culture were made to influence locals to view the colonial culture as the best, while their own culture was doomed. It is therefore the black experience, in the wake of many forms of black oppression (e.g. colonisation, racism and others) that orchestrates the perception that blackness is worthless. The infiltration of this kind of perception ensures that a black person does not regard himself or herself as having all the qualities of life, just as is the case with any other race.

\section{As Fanon (1952) articulates:}

The black man is required not only to be black but he must be black in relation to the white man. It is the internalization, or rather [as Fanon calls it], the epidermalization, of this inferiority that concerns him. When the black man comes into contact with the white world he goes through an experience of sensitization. His ego collapses. His self-esteem evaporates. He ceases to be a self-motivated person. The entire purpose of his behavior is to emulate the white man, to become like him, and thus hope to be accepted as a man (Mazama 2015).

Fanon's short-lived colonial experience not only taught him to write about Algerian inequality but also informed him sufficiently to vividly expose that the colonised black man wants to turn his race white (Fanon 1952:xiii). Another reasoning that has a big influence, according to Simmons (1978:56), is that an individual's negative or positive attitude towards himself or herself is influenced by the larger society and the opinions of significant others in his or her immediate environment. This view may not be used to degrade the value of ubuntu, which works from the conception that 'I am because you are'. For Africans, this conceptualisation is a good tool to be used to explain caring for one another, but when Western civilisation and colonisation entered black lives, this sound approach was turned on its head and abused to make black people feel inferior as people. Ramantswana (2016) provides a good explanation for the dislocation of the black mindset that causes black people to see themselves as minors:

The colonization of the African mind turned the Black epistemologically white by making blacks turn against their own institutions and knowledge systems, thereby regarding them as primitive. First the colonialists systematically suppressed African modes of knowledge and of production of knowledge and meaning, their beliefs and cultures. (p.187)

Self-hatred, amongst other things, is the fruit of what Ramantswana (2016:185) calls the 'colonization of the mind that cuts across the line'. The imposition of the colonial system of education was inflicted on the minds of the indigenous people, to the extent that it did not allow the nonWesterner - particularly the black Africans - the ability to reason philosophically, thereby turning them away from themselves (Cloete 2016:21). There is no doubt that European colonialists defined black people as degraded people, incapable of achieving many things - including salvation while they thought of themselves as the embodiment of a saving grace (Vesely-Flad 2017:196).

\section{Practical signs of self-hatred Lost African leadership}

When highlighting negative forms of leadership in Africa, Moss (2007:38-39) argues that Africans have failed to 'tame' ethnocentrisms, and hence, there is a crisis of leadership. Common practice is that, even when voting, people support candidates from their own ethnic community, rather than voting for the most qualified candidate. African leadership has been found wanting from different perspectives, including in the church and academia. That is why Tshaka (2013:182) argues that, amongst other things, the death of African leadership is being caused by the theological methods used in mainline church seminaries and universities, which fail to equip leaders with tools that are relevant to their context and praxis. By contrast, Ashimolowo (2007:222) finds it hard, while looking at the continent, to quote African leaders who can be said to have transcended their tribal, cultural and geopolitical acceptance. Chief Justice Mogoeng Mogoeng is correct in saying: 'If there was ever a time to embrace ethical leadership, that time is now'. Trevor Manuel, when delivering the keynote address during the Kader Asmal memorial lecture at the University of Cape Town in May 2017, said: 'Moral and ethical leadership is important for the economic drive of our country'. My contention is not that we do not have leaders: the challenge is the kind of leadership we have. In an African context, when we speak of moral and ethical leadership, we cannot neglect the role of ubuntu as well as the communal 
spirit that makes a leader part of his or her own community, without betraying the people in any way. The relevance of leadership needs to be informed by the context and circumstances of the immediate people it desires to serve. In the article entitled 'Unpacking the downside of sustentasie on African theology and theologians', I argue that as long as black pastors remain stuck, earning a living by begging from a white church, their theological relevance will remain questioned by the people they claim to lead (Baloyi 2016). The only mandate black people take pride in is to maintain and defend whatever the white church has left for them, without questioning their theological conviction. African reflections on Western theology will not be given a space at all; hence, one can demonise whatever a black community thinks, for no apparent reason. It is the very same lost leadership that was supposed to play a role in addressing some of the issues affecting black people, which include xenophobia and Afrophobia.

\section{Xenophobia and Afrophobia}

These are two concepts that can be used to describe a situation where a black person has hatred towards another black person. It is not the focus of this article to get into the finer details of the difference between the concepts, but it is important to note that the focus is on self-hatred that manifests itself in the form of fighting and even killing, which happens amongst black people of African origin. In recent years, this country has experienced xenophobic attacks on African black people who are not South African nationals. This aligns with what Fanon (1952:xiv) means when he says that as one begins to recognise that the Negro is the symbol of sin, one catches oneself hating the Negro.

Because these attacks targeted black Africans who were foreign to South Africa, rather than nationals from other parts of the globe, Tshaka (2013:184) prefers to call this evidence of Afrophobia. For the sake of this article, the concepts are interchangeable, as the essence is that it is black-on-black violence - it fits so well into that kind of self-hatred which enables black people to hate and fight those they are supposed to shield. I am reminded of the biblical story in which Moses finds two Hebrews fighting with each other and says:

The next day he went out and saw two Hebrews fighting. He asked the one in the wrong, 'Why are you hitting your fellow Hebrew?' (Ex 2:13)

Besides this, Baloyi's (2015) article entitled 'The Christian church's role in the escalating mob justice system in our black townships' exposes how black people in black residential areas experience vigilantism, which promotes the killing of fellow inhabitants, sometimes for reasons that will not stand if the spirit of ubuntu is allowed to take control. Dealing with xenophobia and Afrophobia demands, amongst other things, our own taboos (which were used to shape black lives) come into play; hence, the next section looks at how our morals are affected when taboos are undermined.

\section{Relegating our own taboos to mere superstitions}

The moral decay that is evident in South Africa lacks, amongst other things, indigenous knowledge systems that promote the very traits which black people abandoned, while embracing white people's culture. One example is the argument Baloyi (2019:5) makes with regard to the role and importance of ignored and undermined traditional taboos amongst the Tsonga-speaking people in the Limpopo Province. In truth, because most of the indigenous knowledge is oral and not written, it is easily judged as mere superstition, while these are in fact traits that used to shape and regulate black people's lives. Afe (2012:96) attests to this by arguing that taboos represented the main source of the guiding principles that regulated and directed the behaviour of both individuals and the community. This is in agreement with Malungana (1999:38) who sees the implementation of taboos as a regulatory process, determining social interaction and community relationships. It is easy for someone who has managed to undermine or relegate his or her own taboos, to progress to a point where he or she demonises some of his or her cultural practices, such as lobolo.

\section{Demonising or abandoning lobolo}

Traditions such as lobolo have become despised and discredited not only by white people but also by black people who are expected to uphold it as part of their traditional values. The blog entitled 'Only fools pay lobolo' is written by a black woman who discourages a practice held in high regard by most black traditionalists (Writer 2012). The indication that this view might have been adopted by many black people is evident in light of how cohabitation and other forms of unions without lobolo are escalating. It matters when other cultures undermine or discourage this practice, but it is even more concerning when those who are supposed to defend the practice speak out against it. This is self-hatred which is trying to take away everything good about black people - a process that they themselves allow and support. These neglected and undermined African issues form part of what is called the African philosophy, which is normally found in the oral traditions of black people. It is for this reason that denying the existence of African philosophy means also rejecting the very idea of philosophy (Ramose 1995:7). Although lobolo practices cut across many African cultures, these often receive criticism along tribal lines.

\section{Tribalism}

The fact that the apartheid system allowed the classification of South Africans into racial groups (white, black, mixed race and Indian) played a significant role in curtailing the rights and dignity of the black races particularly (Magezi \& Tenai 2017:62). According to Kasfir (1976:77), African politics and leadership are also centred around ethnicity. There is evidence to prove the continued existence of tribalism in South Africa. The tribal fights and conflicts that rear their ugly heads are the result of apartheid having 
taught black people to hate one another, which is another form of self-hatred. Much as is the case with slavery, apartheid used to capitalise on the differences between ethnic groups, in order to control them. This notion was taken from the practice where slaves were controlled by their masters (Tshaka 2013:189) in a system known as 'divide and rule'. Another factor that has proven to be useful for fuelling self-hatred through tribalism is the use of language to create tensions and tribal divisions. The fact that different ethnic groups have their own languages has been used as a tool to foster hatred between black communities. This is what the Vendas and Tsongas are using to fuel their rivalry in the Synod Soutpansberg of the Reformed Churches of South Africa, as argued by Baloyi (2016). It is but one example of many which demonstrate pure tribal conflicts in South Africa. This is testimony to the fact that black people have successfully internalised self-hatred, to the extent that, instead of facing the real colonial enemy of their humanity, they concentrate on fighting each other over minor issues. Cloete (2016:1) clarified this when he argued that a black man behaves differently towards a white man than he does towards a fellow black person. One of the negative effects of tribalism is the fuelling of genocide in many African countries, and thus, the next discussion is also important in this regard.

No continent in the world has experienced genocide like Africa has. It is estimated that 800000 Rwandans were killed in the space of 100 days during the genocide in Rwanda, between April and June 1994 (BBC News 2011). This is an example of black-on-black political killing. For Cloete (2016), the colonisation of the New World amounted to genocide.

\section{Academic and professional context}

Prof. Bonke Dumisa (2013) once gave a lecture in which he told a painful story about black-on-black violence in South Africa:

Challenges to black intellectuals, black professionals, and black entrepreneurs are definitely not confined to KwaZulu-Natal; this is a national phenomenon. Nelson Mandela, the world political icon and first President of the post-apartheid Republic of South Africa, was sometimes justifiably criticised of being very intolerant of any criticism by anyone black, despite the fact that he would always go out of his way to 'embrace the rainbow nation' in addressing the sensitivities of most racial minorities. (Mazama 2015)

Interestingly, the world renowned playwright and novelist, Zakes Mda (2011), comments in his book Sometimes There Is a Void that he was regularly asked by non-South Africans whyhe chose to live in America, and not in post-apartheid South Africa. His response is as follows (Mda 2011):

I have skills for which I am highly trained. I can't practice them in South Africa because all doors are closed by the vast patronage system and crony capitalism that emerged in my beloved country. Doors were banged in my face, that's why when the opportunity availed itself I left, though it was a difficult decision.
We go to where our skills are appreciated first and foremost, and then of course rewarded. (Mazama 2015)

Mda reported that Mandela often accused him of being 'too outspoken' and, because of this, he found himself and members of his family marginalised in South Africa. It is within this framework that black people are being marginalised by other black people for their convictions and straightforwardness. This is where black professionals and academics feel strongly that self-hatred is entrenching what apartheid aimed to achieve, and it is observable for more than 20 years into democracy.

Besides the other forms in which self-hatred manifests itself, academia is an area that faces the problem in practice. Firstly, many journals in which academics should and could express their thinking by publishing their work are white owned. The deciding factor in a particular journal thus lies within the jurisdiction of the editor, who determines what can and cannot be published. Many scholars find their thoughts being compromised, because if they write about issues around black culture or black resistance, they find their articles being denied for publication.

In other instances, when a black person is promoted to lead a department or college, many black scholars will offer blind and unconstructive criticism, even on a personal level. Instead of trying to support the incumbent with ideas for improvement, they will try to discredit and even disrespect him or her, to make him or her feel like a failure.

In academia, most black people opt to write and publish what will romanticise their white 'gatekeepers', so that they can continue to be published in their journals. If they write something that is offensive to white people, it may not be published. Sometimes co-authoring and mentoring are looked at in terms of white-superior and black-inferior, because knowledge is believed to come from the white masters. My article 'sustentasie' (Baloyi 2015) argues how black church leaders become spies for their white counterparts, for the sake of securing their continued support, and this is evidence of their self-hatred towards their own black brothers and sisters. Black leadership is despised in higher academic institutions, not only by white people but also by our black brothers and sisters. For instance, when a black person becomes a manager, his or her own black people will start looking for weaknesses and seek to exploit him or her, instead of supporting and helping him or her. It is still widely believed that, for good investments when purchasing property such as houses and cars, the buyer needs to check whether the previous owner was a black person or a white person: if the owner was a white person, preference is given to that item. That is why many well-to-do black people prefer run to buy homes in former white areas. All the subsections above make important points when arguing that self-hatred is a very real problem for many black people. Some of the consequences of self-hatred are discussed in the next subsection. 


\section{The consequences of self-hatred}

Many black South Africans are seen to be scoring 'own goals', because they cannot engage on issues that may transform their lives. This resonates with Opoku (2012) view:

A seemingly lasting effect of missionary teaching is the uneasy attitude, nay the fear, most African Christians have about their culture and the timorously hesitant approach of the church to most things African. (p. 14)

In this way, black people despise their own culture and traditions, while trying to protect whatever watered-down 'culture' was left for them by the colonialists. In the African tradition, a boy cannot say anything against his master, and because our fathers were made to believe they were boys, when compared to white men, their low self-esteem would not allow them to have their own, unique voice (Baloyi 2016:5).

\section{Stereotyping}

One of the many examples of stereotyping with regard to black self-hatred is evidenced when O. Lloyd Douglas (2013) articulates:

There is so much negativity and criminal suspicion associated with being a black male in Toronto. Yet, I don't have a criminal record, and I certainly don't associate with criminals. In fact, I abhor violence, and I resent being compared to young black males (or young people of any race) who are lazy, not disciplined, or delinquent. Usually, when black male youth are discussed in Toronto, it is about something going wrong. (p. 1)

This kind of depiction remains in the black mind, to the extent where when one black person sees another black person, they start preparing themselves for violence or an attack, not only in America but also in South Africa. Even as regards issues of dress, many black people are not happy to dress in their traditional attire, but are more comfortable in being dressed like Europeans. A good example is African women buying wigs and extensions, or changing their hairstyle. Many dislike their natural short hair, not because there is something wrong with it, but because they prefer long hair that makes them look like their white mistresses. Pinkney (2014:98) argues that society's standards of beauty for men and women still include light skin, having long hair, being curvaceous and attractive.

Fanon (1952) clearly depicts what self-hatred can do to a black mind, namely getting someone to try to be something or someone he or she is not. This is how Fanon explored the nature of colonialism and its psychological damage to the minds of colonised peoples. Even in the workplace, if the leader is a black person, his or her every mistake and fault will be found and highlighted to cast doubt on his or her leadership, but if someone of another race is the leader, his or her faults will be covered up, as if nothing happened at all.

\section{What can be done or the way forward}

The real question we need to start addressing with regard to this issue is to be uncompromising and ask the question which Malcolm X (in Senokoane 2019) posed in a speech delivered in Los Angeles:

Who taught you to hate the color of your skin? Who taught you to hate the texture of your hair? Who taught you to hate the color of your skin, to such extent that you bleach to get like the white man? Who taught you to hate the shape of your nose and the shape of your lip? Who taught you to hate yourself, from the top of your head to the soles of your feet? Who taught you to hate your own kind? Who taught you to hate the race that you belong to - so much so that you don't want to be around each other? (p. 3)

If we cannot identify the cause of our problem, we are likely to spend more time without a solution. That is what the slain Black Consciousness leader, Steve Biko (1978), said: 'The most important weapon of the oppressor is the mind of the oppressed'. Captured as we are, we have become a shadow of ourselves, but not by choice. The colonial powers have made us believe we are less than human beings if we are not up to the standards of our colonisers. This was one of the successes of colonisation: making us more dependent on the colonisers, because they determine our way of life and our standards. It is in similar vein that fuel prices, amongst many other things, are not determined by ourselves.

It is a major concern for black theology and theologians that, at the point of liberation, theology emphasises the call for social, economic and political transformation and the right of self-determination for black people, while theology legitimises such processes (Magezi \& Tenai 2017:63).

The first and most important thing to mention is that the liberation of black people lies in the hands of black people themselves. It is imperative that black people ensure that all oppressive symbols within their culture be removed, so that new, liberating symbols can emerge (Lartey 2013:227). This means that it is our responsibility to dismantle artefacts or songs that remind us of our inferiority complex, as we work to embrace new perceptions of ourselves. It would be suicidal, for black community as a people, to expect our former oppressors to become our liberators. That is where my question becomes relevant: 'Who is qualified to decolonise?'

My recommendation is that the liberation theology of James Cone and others become more relevant in liberating black people from self-hatred. Although Fanon's anger was not directed simply at the black man, he made a good point in suggesting that liberation can begin by recognising constructions of blackness as they are. This will help the black person to start saying NO:

No to degradation of man. No to exploitation of man. No to the butchery of what is most human in man: freedom. And, above all, no to those who attempt to build a definition of him. (Fanon 1952:xiv)

The deformation of our African identity, which we as Africans allowed to happen by justifying Western epistemologies as the only correct ones, created an impression that African philosophies, traditions and lifestyles are unacceptable and 
deniable. For this, not only is the study of our own history necessary but we also need to advocate for the transformation of the curriculum from the core. This is what Ramose (Ramose: Discourses in Africa) terms the 'de-liberation' of our own philosophies over Western epistemologies. The one-sidedness of the information, knowledge and education that was fed to black people only managed to turn them against themselves, and deliberately excluded, omitted and ignored African history. Therefore, authentic liberating knowledge should be inclusive of the other (Ramose: Discourses in Africa).

This exercise can take place by considering the question of who the rightful people are, to take on the task of decolonising and de-liberating us. My argument here is that we cannot have a genuine reversal of the wrongs of the past if we still allow the very same people who intentionally and deliberately excluded our history to be the leaders of the project of our decolonisation. Sekou Toure (quoted by Biko 1978) states:

To take part in the revolution, it is not enough to write a revolutionary song, you must fashion the revolution with the people. And if you fashion it with people, the songs will come by themselves and of themselves. (pp. 34-35)

An African theologian, Kwame Bediako (2018:83), grappled with the question of identity. He asked: 'Who am I in the midst of the colonisers?' That question, of course, speaks to the nature of a person, and the way he or she is supposed to conduct himself or herself. This is in line with what Fanon $(X X X)$ calls 'numerous colonial dichotomies', which include the pagan, civilised, saved, guilty and others, which were used to replace our identity in trying to redefine who we as black people are in the face of colonialism. This is the pathology that, if not arrested, will prevent black people from succeeding on the road to decolonisation. It is the undeniable truth that we are not going to uproot the attitude of white supremacy unless we deal with the black condition, because white supremacy is founded on the black condition (Malema 2016:1).

Liberation theology needs to offer appropriate responses to people's circumstances, including the issue of self-hatred, which is a sign of a dehumanised image. In the reconstruction that must take place in black lives, the book by Jesse Mugambi (1995), entitled From Liberation to Reconstruction: African Christian Theology After the Cold War, will make a significant contribution. The church's counselling ministry should be handled more effectively, to bring about realistic adjustments for black people (Lartey 2013:232).

People, regardless of race or colour, need to understand the concept of being created in the image of God. Theology has all the ingredients that can assist in defining and explaining the image of God. Pastors and preachers should play their role in discouraging any form of racial inequality, as well as ensuring the correct teaching of imago Dei, so that black people can see themselves as equal beings to their white counterparts. Baloyi (2012:4) is correct in arguing that the church, amongst others, must be instrumental in changing people's perceptions about others.

\section{Language}

Fanon (1952:xv) indicates that, from our colonial past to the present, a black man was expected to speak in a European language, particularly English. In the South African context, the evidence of black ethnic groups undermining and tormenting one another based on language is clear; for instance, in most parts of Pretoria, now called Tshwane, Vendaand Tsonga-speaking people are not taken seriously or else tend to be called makwerekwere. For the fact of having named the city 'Tshwane' (a Sotho name) led many Sotho-speaking people to understand that this is their place, and other languages are made to feel unwelcome. This is connected to the issue that caused the African National Congress (ANC) to lose power in Tshwane in 2016, when it became clear that Thoko Didiza is of Zulu origin, and as an ANC candidate she was not welcomed by the locals who preferred a Sotho candidate. In the article 'Language as a dividing factor', Baloyi (2016) indicates how the issue of language between the Venda- and Tsonga-speaking people in Limpopo is widening the gap apartheid created between the two tribal groups.

\section{Conclusion}

Self-hatred amongst black people is a very serious issue, which manifests itself in many forms, including we as black people abandoning our culture, becoming tribalist and xenophobic, amongst others. When everything about being black was demonised, the majority of African blacks were left only with having to see themselves as shadows of what the West represented. The consequences of such stereotyping are clear, for instance, with black people trying to be something they are not, at great cost to their own identity. To decolonise ourselves, liberation theology is needed, by which we need to start accepting ourselves as we are, after asking ourselves who we are. The black community needs to deny anything that works to degrade their lives, culture and behaviour. As black people, we should reflect a true black conscience, in the midst of those trying to shape our lives according to Western ideologies and standards. To end, this quote is appropriate:

But the dominance of western culture, and its globalization through this dominance, should not be confused with universalism. Just because a particular discipline or a discourse is accepted or practiced throughout the world, it does not mean that discipline or discourse is universally valid and applicable to all societies. (Fanon 1952:xvi)

\section{Acknowledgements Competing interests}

The author declares that no competing interest exists.

\section{Author's contributions}

I declare that I am the sole author of this research article. 


\section{Ethical consideration}

This article followed all ethical standards for carrying out a research without direct contact with human or animal subjects.

\section{Funding information}

This research received no specific grant from any funding agency in the public, commercial or not-for-profit sectors.

\section{Data availability statement}

Data sharing is not applicable to this article as no new data were created or analysed in this study.

\section{Disclaimer}

The views and opinions expressed in this article are those of the author and do not necessarily reflect the official policy or position of any affiliated agency of the author.

\section{References}

Afe, A.E., 2012, 'Taboos and the maintenance of social order in the Old Ondo Province, Southwestern Nigeria', African Research Review: An International Multidisciplinary Journal 7(1), 95-109. https://doi.org/10.4314/afrrev.v7i1.7

Ashimolowo, M., 2007, What is wrong with being black? Celebrating our heritage, confronting our challenges, Destiny, Shippensburg, PA.

Baldwin, J.A., 1979, 'Theory and research concerning the notion of black self-hatred: A review and reinterpretation', Journal of Black Psychology 5(2), 51-77. https:// doi.org/10.1177/009579847900500201

Baloyi, M.E., 2012, 'The use of Imago Dei as a pastoral healing vision against women killings in the South African context', Verbum et Ecclesia 33(1), Art. \#703, 6 https://doi.org/10.4102/ve.v33i1.703

Baloyi, M.E., 2015, 'The Christian church's role in the escalating mob justice system in our black townships - An African pastoral view', HTS Teologiese Studies/ Theological Studies 71(2), Art. \#2833, 7. https://doi.org/10.4102/hts.v71i2.2833

Baloyi, M.E., 2016a, 'Unpacking the downside of sustentasie on African theology and theologians: A need for contextual black theology as a liberative ingredient for the black Reformed churches', HTS Theological Studies 72(1), 1-8. https://doi. org/10.4102/hts.v72i1.3161

Baloyi, M.E., 2016b, 'Language as a dividing factor amongst the Reformed Churches in South Africa: A case study of the Soutpansberg Synod', Journal of Theology for Southern Africa 154(March), 43-58.

Baloyi, M.E., 2016c, 'The "vat en sit" unions as a threat to the stability of African marriage in South Africa', Phronimon 17(2), 1-16. https://doi.org/10.17159/2413marriage in Sout

BBC News, viewed 17 May 2011, from www.bbc.com

Bediako, K., 2018, 'An act of theological Negritude', in S.T. Fretheim (ed.), Emerging Religious Discourse in twentieth century Ghana, Pickwick Publications, Eugene, Oregon.

Biko, S., 1978, I write what I like, The Bowerdean Press, London.

Bonke, D., 2013, On the marginalization of black intellectuals: News and analysis, viewed 12 March 2018, from www. politicsweb.co.za.

Cloete, M., 2016, 'Innocence and the struggle for humanity', Acta Theologica 36(suppl. 24), 17-42. https://doi.org/10.4314/actat.v36i1.3s

Donaldson, C., 2018, Hair alteration practices amongst black women and the assumption of self-hatred, viewed 15 February 2018, from http://wp.nyu.edu.
Douglas, O.L., 2013, Why I hate being black man, viewed 18 March 2018, from www. theguardian.com.

Fanon, F., 1952, Black skin, white masks, Grove Press, US.

Gumede, V., 2016, 'The South Africa we do not want to know', Mail \& Guardian, viewed 31 January 2018, from http://thoughtleader.co.za.

Hooks, B., 1992, Black looks: Race and representation, South End Press, Boston, MA.

Kasfir, N., 1976, The shrinking political arena: Participation and ethnicity in African politics with a case study of Uganda, University of California, Berkeley, CA.

Kunhiyop, S.W., 2009, 'The challenge of African Christian morality', Consectus 7(1), $60-75$.

Magezi, V. \& Tenai, N.K., 2017, 'Black theology and its response to poverty in the black sphere: A case for Africa Inland church in Kenya', Journal of Black Theology 15(1), $60-78$.

Malema, J., 2016, 'Why do white people despise blacks? A real estate life', Times Live, viewed 15 January 2018, from www.timeslive.co.za.

Malungana, S.J., 1999, 'The relevance of xiTsonga oral tradition', Alternation 6(1), $37-54$.

Martey, E., 2013, 'Spiritual challenges of widowhood symbolism in an African religiocultural setting', in S. Marks \& A. Clapham (eds.), Internationalized human rights, pp. 129-149, Oxford University Press, Lexicon.

Masenya, M., 2018, 'Politically freed yet mentally enslaved', in W. Ackah, J.E. Edson \& R.D. Smith (eds.), Religion, culture and spiritually in Africa and the African diaspora, pp. 144-157, Taylor and Francis Group, Routledge, NY.

Mathope, G., 2017, 'The problem with Africans is self-hatred and self-rejection Malema', The Citizen, viewed 18 March 2018, from http://citizen.co.za.

Mazama, A., 2015, Racism in schools is pushing more black families to homeschool their children, viewed 18 March 2020, from http://www.washingtonpost.com.

Mda, Z., 2011, Sometimes there is a void: Memoirs of an outsider, Penguin Books, Cape Town, South Africa.

Mkhize, N., Bennett, J., Reddy V Moletsane R, 2010 , The country we want to live in: hate crimes and homophobia in the lives of black lesbian South Africans, Policy analysis and capacity enhancement research programme occasional paper 1 , University of Cape Town, Cape Town.

Mofokeng, T., 1988, 'The black Christians, the Bible and liberation', Journal of Black Theology 2(1), 34-42.

Moss, T.J., 2007, African development: Making sense of the issues and actors, Lynne Rienner, London.

Opoku, K.A., 2012, 'Skinny but imperishable truth: African religious heritage and the regeneration of Africa', Studiae Historiae Ecclesiasticae 38(suppl.), 141-151.

Pinkney, C., 2014, 'The effects of internalized oppression on the black community', Stylus knights write showcase special issue, Spring 2014, 94-100.

Ramantswana, H., 2016, 'Decolonizing biblical hermeneutics in the South African context', Acta Theologica 36(suppl. 24), 178-203. https://doi.org/10.4314/actat. v36i1.11s

Ramose, M.B., 2003, 'Discourses on Africa', in P.H. Coetzee \& A.P.J. Roux (eds.), The African philosophy reader (2nd edn.), pp. 1-114, Routledge, New York.

Senokoane, B.B., 2019, 'The escape of the black self', Unpublished paper, University of South Africa, Pretoria.

Shange, N., 2018, 'Six hate crimes that shocked South Africa', Times Live blog, viewed 15 February 2018, from www.timeslive.co.za.

Simmons, R.G., 1978, 'Blacks and high self-esteem: A puzzle', American Sociological Association 41(1), 54-57. https://doi.org/10.2307/3033597

Tapper, L.E., 2009, 'Whose reflection is that in the mirror?', The New Black Magazine, viewed 05 June 2019, from www.thenewblackmagazine.com.

Tshaka, R.S., 2013, 'Do our theological methodologies help us to deal with situations of violence in black communities, specifically Afrophobia?', in R. Badenberg, R. Ebeling \& E. Meier (eds.), So ganz anders: Fremdheit als theologisches und gesellschaftliches Phanomen.

Vesely-Flad, R., 2017, Racial purity and dangerous bodies: Moral pollution, black lives, and the struggle for justice, Fortress Press, Minneapolis, MN.

Writer, G., 2012, Only fools pay lobola, viewed 19 November 2012, from www. justcurious.co.za. 